\title{
Islamic Criminal Law: The Divine Criminal Justice System between Lacuna and Possible Routes
}

\author{
Arafa MA* \\ Indiana University Robert H. McKinney School of Law, Indianapolis, United States
}

*Corresponding author: Arafa MA, Adjunct Professor of Islamic Law and Middle Eastern Legal Studies, Indiana University Robert H. McKinney School of Law, 530 West New York Street, Lawrence W. Inlow Hall, Indianapolis, IN 46202, United States, Tel: +1 (317) 274-8523, E-mail: marafa@iupui.edu

Citation: Arafa MA (2018) Islamic Criminal Law: The Divine Criminal Justice System between Lacuna and Possible Routes. J Forensic Crime Stu 2: 104

Article history: Received: 05 March 2018, Accepted: 27 March 2018, Published: 29 March 2018

\begin{abstract}
The Islamic legal system differs from other legal attitudes, as civil law traditions described by law's codification or common law practices based on binding judicial precedents. In Islamic law, there is neither history of law's classification, nor an understanding of binding legal precedents. The process of ijtihad (analogical deduction) in Islamic (Sharie'a) law, though, is alike to Case law model. This article discusses the main principles of criminal law substantially and procedurally and the rules of evidence for each crime is so strict and need a lot of work to proof its commission and to apply the punishments, so it sounds stricter in application than the positive laws without any contradiction to them, so it outlined and described the essential features of Islamic criminal law. Some scholars argued that international human rights values should be interpreted, applied, and practiced by domestic cultural and religious ideals. Islamic criminal law is genuinely rooted in the revelations' tests and as such is divinely based and driven, not to remark circuitously mingled with spirituality and ethics while instructing human dignity's philosophies and life appreciation's values. So, in the end, as the Islamic human rights law charter is earlier than the Human Rights Declaration, so we may not ask ourselves if Islamic law is compatible with HR so, instead, we may ask which parts of the that law or the Sharie'a norms are similar to the HR Declaration and how they are applied in each country.
\end{abstract}

Keywords: Criminal Law; Human Rights

\section{Introduction and Overview}

The Islamic legal system varies from other legal approaches, as civil law practices described by law's codification or common law traditions based on binding judicial precedents. In Islamic law, there is neither history of law's codification, nor an apprehending of binding legal precedents [1]. The process of ijtihad (analogical deduction) in Islamic (Sharie $a$ ) law, though, is alike to Case law analysis. In this respect, Muslim scholars have had over the understanding and interpretation of the Sharie' $a$ norms and divine (God)'s law based on the Qur'anic texts and the authoritative Sunnah (Prophet Mohammad) teachings [2]. The principal sources of Islamic criminal law are the Qur'an, Sunnah, ijma'a (consensus), Qiyyas (individual reasoning) along with other sources [3]. Where the principles of the Qur'an and Sunnah do not sufficiently resolve a legal issue, Muslim intellectuals use Fiqh, which is the process of inferring and applying Sharie' $a$ norms to reach a legal purpose and its methodologies and implementation are numerous, as various schools of jurisprudential (Sunni and Shie'a) thought (Hanafi, Maliki, Shafi $i$, and Hanbali) emerges [4]. Based on this succinct backdrop, this article will delve in elaborating the main principles of the Islamic criminal justice system and proof that it is totally is similar to the positive secular criminal justice mechanisms.

\section{The Relation between the State and Religion}

In all Muslim nations, the legislative power of the state is legally based on the domestic constitution. Also, the national legislature has a religious (divine) legitimacy on the basis of its siyasa (policy) authority to enact laws and regulations as long as they do not contradict the main principles of Sharie' $a$ [5]. This raises the inquiry of which interpretation of the Islamic law applies - modernist, conservative or otherwise and rudimentary norms offers states both an Islamic legitimacy as well as a space for independent expansion of national law [6]. The focus of Islamic law is family law, which has to a significant extent been transformed through legislation. New family law combines traditional (classical) and modernist elements, occasionally in vague formulations [6]. Several norms, which can be seen as procedural elements of the rule of law, have been presented to bound the unilateral power of folks by providing public institutions with powers of registration, of supervision, and of decision making [7]. From time to time, Islamist 
factions in congresses propose bills with an 'Islamist flavor' without express reference to Sharie'a, as the Anti-Pornography Bill in Indonesia, which aroused much criticism as an example [8].

Most Muslim countries have laid down their criminal law in modern contemporary criminal codes. A major exception is Saudi Arabia, which has reliably maintained Islamic criminal law, although, surprisingly, in 2001, it endorsed a new criminal procedure law [8]. Since the 1970s, some countries have decided to comprise elements of classical Islamic criminal law - especially in the area of hadud crimes - into the current modern criminal law codes or relevant legislation [9]. However, the same countries have in recent years become progressively cautious when it comes to actually carrying out the more serious hadd penalties [9]. Supreme courts infrequently - such as in Sudan and Iran - or never - such as in Pakistan and Nigeria - maintain convictions of stoning or amputation and in Saudi Arabia, severe corporal punishments are still carried out regularly [10]. After totally unfair trials in Pakistan, the Islamic principle of retribution or revenge (retaliation), with strong roots in customary law, was re-imposed in criminal law in the 1990s and is still often applied [11]. On the other hand, Saudi Arabia, did not sign the UN declaration of Human Rights in 1948, arguing that it violated Islamic law with zero knowledge of their argument, but most Muslim-majority countries including Egypt, Iran and Pakistan signed it. But crucially Saudi Arabia, where the King must comply with Sharie' $a$ and mainly the Quran, did not sign the declaration, arguing that it violated the main Sharie' $a$ norms and criticizing it for failing to take into account the cultural and religious context of Muslim (non-Western countries) [11]. Saudi Arabian law is completely at odds with the UDHR as all citizens are required to be Muslim which is totally against the main Islamic values. For instance, women are prohibited from voting or driving a car, and that's recently lifted arguing that they wanted to change the very extreme wahabism or salfaism thoughts [12]. A part of their argument also associated with that the UDHR was a "secular understanding of the Judeo-Christian tradition" and that it is impossible for Muslims to implement it without contravening Islamic law. On closer inspection of the right to freedom of religion in Islam as an example, it is possible to see a mass of paradoxes. On one hand, apostasy (ridda) is considered by some as punishable by death and some schools of Islamic fiqh (jurisprudence) assert that any Muslim can kill an apostate without punishment, and that's absolutely wrong and creates a big confusion, but on the other hand, the Qur'an teaches that there is "no compulsion in religion" and "to you your religion, to me mine" and Mohammad famously declared freedom for Muslims, Jews, Christians, and Pagans in the constitution of Medina in 620AD [12]. Thus, the Islamic Caliphate introduced religious freedom for non-Muslims and to pay the jizya tax instead of the zakat tax that Muslims had to pay. In 1990 Islamic countries created their own Human Rights Charter called the "The Cairo Declaration of Human Rights in Islam” and 58-member countries signed, as Egypt, Indonesia, Iran, Iraq, Jordan, Lebanon, Libya, Malaysia, Pakistan, Syria, Turkey, among many others. Some of the criticisms from the West included that men are equal and women are not, affirming the superiority of men; no one is free to change religions and women are not free to marry outside of religion; punishments according to Sharie' $a$ law, non-criticism of religious figures, cannot "undermine moral and ethical values or disintegrate, arouse nationalistic or doctrinal hatred" or commit an "incitement to any form of racial discrimination" within the ummah (community), and it introduces intolerable discrimination against non-Muslims. Muslim countries argue that CDHRI declares "true religion" to be the "guarantee for enhancing such dignity along the path to human integrity" and places the responsibility for defending those rights upon the entire Muslim nation in which the meaning of this argument is not clear and creates a lot of confusion to western communities [13]. For me, generally denying signing a human rights charter or document represents a clear attempt to limit the rights enshrined obviously under Islamic human rights law and humanitarian law charters, the rights emphasized by the UDHR and the international Covenants - in which there are totally wellmatched to Islamic norms - under indefensible or non-sense arguments that it contradicts Islamic law values, and HR documents should come from Islamic or Qur'anic law, and then will take precedence over the UDHR, as this can in no sense be seen as an illegitimate complementary tool for transgressing human rights.

Muslim law was a policy of kind of a source including system of sentences for breaching the law and regulating way of using them. Since creation of the Ottoman Empire, it means from 1299-year, significant impact on a criminal law has been having law made by the rulers [13]. What is more, in Saudi Arabia, there is a quit application of punishments based on in accurate interpretation of Islamic law as in case of using or drinking alcoholic beverages, and even sexual deviations (adultery) [13]. Many of Muslim criminal law rules describing Islamic criminal law as it represents an extreme case of "jurist law" which means that it was shaped and established by private religious experts. Accordingly, it should be noted that it is complicated to apply this law as it requires very higher standards of proof and rigorous evidences as more than beyond reasonable doubt norm. The complexity and uniqueness of law regulations in Muslim law. Undoubtedly from the "western" point of view, the main problem is to understand the mechanism of the application of corporal and capital punishment.

\section{Islamic Penal Justice System: Quo Vadis?}

As Islamic criminal jurisprudence is unique in guaranteeing the right of individual personal peace and security, as Islam assure makasid al-Sharie' a al-Islamia (five essential things) to all folks and forbids unjustified violation of them by the State [14]. In order to have an accurate understanding of the Islamic criminal (penal) justice system, it must be viewed in the light of the following main features derived from the Qur'an and the Sunnah: (a) that which is not haram (prohibited) is mobah (permitted); (b) rules, prohibitions, and even unequivocal injunctions are often based on genuine events and not conjectural situations (increases the option for analogical reasoning); (c) the language used in the warnings permit for policy-geared interpretation and implementation, based on sound policy reasoning and social necessity; (d) the express language used in specific bans is often qualified by other texts permitting the legal excuse of justification along with judicial discretion; (e) evidentiary prerequisites [anticipated to restrict 
judicial discretion and make it more tough to find a suspect guilty and enforce a punishment concerning particular criminal acts] temper the ostensible punishment's severity; (f) prohibitions on criminal justice are not focused in any one part of the Qur'an or the Sunnah, but are combined among a diversity of other matters; ( $\mathrm{g}$ ) the creation of procedural guarantees, intended to safeguard the individual from judge's power and other's abuse, and protects the individual's rights; (h) codification and lawmaking are acceptable in all three classes of offenses, with discretion permitted in ta'azir criminal acts; (i) punishments for each crime's sort fluctuate, therefore proving a different philosophy and penalty's policy; (j) sentences are envisioned basically as deterrents, though highlighting is also placed on reintegration, mostly in ta'azir crimes, with a robust trend for compensatory sanctions (non-penal) in qisas crimes, and finally $(\mathrm{k})$ issues about criminal justice (crimes, punishments, evidentiary rules, procedures, trials, etc.) are mentioned to contextually as part of various Qur'anic verses, emphasizing the social and moral aspects of criminal justice [15]. Yet, these features depend on the appropriate source of law selected, its rank among other sources and their linkage, according to the valid interpretations rules underscored by usul al-fiqh (Islamic jurisprudence) science [15].

\section{Substantive Islamic Criminal Law: Do You Think it is Scary, Versus Human Rights?}

Islamic law offers the structural framework for the ummah (society) by conserving the legal relations among individuals and defending their interests from being attacked by another in which the most important principles laid down in the Sharie' $a$ are to determine the linkage between the state and the person in case of a crime committed are: (a) the principle of individuality of the criminal liability; (b) the legality principle, and (c) the non-retroactivity principle of criminal laws [16]. This principle of uniformity of criminal liability is the cornerstone of personal security in Islamic criminal justice means that the offender himself is the only person who can be indicted of a specific crime, and no one shall escape punishment irrespective of blood ties or friendship to the victim (or to the judge or ruler) [17]. A person, who has contributed in a forbidden act, whether as principal or accomplice, must be convicted according to this norm [18]. On the other hand, to avert the power abuse, persons cannot be accused of crimes for acts which were permitted when committed [19]. Thus, Islamic criminal system has recognized the principle of nonretroactivity of criminal laws as a main basic of its criminal justice system; this rule means that criminal laws have only eventual and not retroactive effect [20]. Equality before the law represents one of the main legal principles under Islamic penal model, as all persons are equal before the law and be applied uniformly regardless of religious or economic status (no immunity) [21]. Thus, both crimes and punishment must apply equally and to criminal proceedings as well. When punishments are individualized, especially for ta'azir offenses, the equality norm is not transgressed where the correction and rehabilitation theories prevail [22]. This principle is a guarantee that the judge will not misuse his/her discretion; as a form of regulating the proportionality [test] of sentences [23].

In the same vein, nullum crimen nulla poena sine lege (the legality principle) generates an essential pledge of individual freedom against powers misuse, corruption in the criminal system, and the judge's bias [24]. Under this norm, there shall be no crime and no punishment except by virtue of law; hence, no act may be considered a breach of law if it has not been unequivocally anticipated in a penal law in force at the time the act was committed [25]. Criminal acts are divided into three classes of crimes: hudud (fixed) offenses are crimes against God whose sentence is stated in the Qur'an and the Sunnah and as a God's agent; the state initiates the prosecution of the offender [26]. Quesas (equivalence) are the criminal acts of murder and physical assault punishable by retaliation, but the victim or (his family) may waive this penalty and ask for diyaa (compensation/blood-money) or 'af $w$ (forgive) the offender (pardon/grace) [27]. Ta'azir are crimes whose sentences are not fixed by the primary sources of the law and are within the qadi (judge)'s discretion [28].

Hudud Criminal Acts: There are seven Hudud (fixed) criminal offenses, five of these acts have a consensus among the Islamic schools on their punishment and two still debatable [29]. Saraqa (Theft) is the taking of the possessions (property) of another whose value is equal to the prescribed nisab (amount), usually set at ten dirhams (about 75 cents to 1 dollar) [30]. In this regard, it is required that the property must be taken from the guardianship (custody) of another in a secret way, and the robber must attain the full property's possession, as this custody condition is fulfilled by the property being under guard or in a place of protection, as in a house and the burglar is punished harshly since it deprives an individual of his property and generates fear, suspicion, and society's apprehension [31]. The first and second acts of burglary are punishable by hands' amputation, and it is commonly approved that the third and fourth crimes are penalized by feet's amputation, though some jurists maintain that the third act should result in incarceration until the offender repentant (reforms) [32]. Theft of some items is not subject to the Hudud penalty and is punished by Ta'azir, as immovables (land and items affixed to it); objects available in large quantities (wood); items typically not subject to proprietorship (fish, birds); perishables (meat, eggs); religious icons and texts (Gospel/Qur'an); invaluable property (alcohol, pork); musical instruments used for indolent amusements; and things not considered as property (children), and theft by an individual's husband, wife, near relative, guest, or so. Other property crimes as embezzlement or misappropriation of public or private funds by an individual who initially obtained legitimate ownership, as bank cashier) or attaining property by false pretenses (fraud) are Táazir crimes.

The offense of zina encompass fornication (sexual relations between unmarried persons) and adultery (sexual relations among individuals, at least one of whom is married) and the Qur'an requires four male eyewitnesses or four confessions on four separate occasions by the defendant in an open court session to guarantee a conviction [33]. Married persons who commit zina are punished by stoning to death, which is not stated in the Qur'an and happened under the Prophet time only twice after the woman have confessed three or four times in front of him and she wanted to be punished and unmarried persons by one hundred lashes 
and exile for unmarried persons are required by some jurists, but not agreed upon [33]. The lodging of zina acts is reserved by the fact that an individual who misleadingly accuses a Muslim of zina is criminally penalized for a qazf (defamation/slander), as defamation also includes doubting the legitimacy of a woman's kid in case of pregnancy [34].

Haraba (Highway robbery) is punishable by amputation and, in some cases, execution, as this crime hinders legitimate commercial activities and creates fear among travelers (mostly merchants) [35]. An impenitent brigand who takes property has his hands and feet amputated and a bandit who homicides is decapitated while a gangster who murders and plunders is penalized by amputation followed by the body's display in a crucifixion form, but intentional banding (murder + plunder) is penalized by a judge's discretionary punishment, frequently imprisonment until the individual regrets [36]. A bandit who willingly surrenders and reforms may be forgiven for this crime and punished only for the other offenses he may have committed, as assault or theft. Additionally, drinking khamr (wine/intoxicating beverages) is punishable by flogging even the number of lashes are debatable among Muslim scholars [37]. The proscription on alcohol has been protracted by analogy to drugs, based on the fact that "drugs have the similar outcome on human mind as alcohol, and they so produce the same public harm that led to the forbidden of the former." [38].

Ridda (apostasy) is the voluntary denial of Islam by a member of the Islamic belief, and is punishable by death penalty according to some scholars, but modern scholars believe that such punishment contradicts the Muslim concept of freedom of religion, as the Prophet said: "No compulsion in religion" and also the Qur'an said "For you your religion, and for me my religion." [39]. Finally, bagi (rebellion) is the deliberate, powerful overthrow or attempted overthrow of the legitimate imam (leader), which is like a coup d'état in the contemporary legal approach [40]. The leader obliged to consider the protestors' demands; but if the requests are irrational (lack merits), he is required to call upon the revolutionaries to end their revolt [41]. Rebels who are murdered are subject to be punished under hudud and protestors who surrender or arrested are subjected to ta'azir; while objectors who are captured in combat are executed (to be free) [42].

Quesas and Diyya(h) Offenses: Quesas (equivalence/equality) related to a criminal act punishable by the same or a significantly similar act in retribution (retaliation) for the harm (injury) inflicted, as Islam considers killing to be the gravest crime against folks [43]. It classified into crimes against the individual (homicide) and crimes against the body (serious bodily injury) [44]. The killer is executed unless the victim's family asks diyaa (h) (compensation) or pardons the criminal. Islamic law identifies numerous sorts of homicide, as alqatl al'md (willful/premeditated homicide) which the intentional killing of another with a lethal weapon or instrument and the offender is subject to retaliation or, if remitted, damages and a loss of any inheritance rights from the victim [45]. Also, alqatl shibial'amd (voluntary manslaughter) is the killing of a person with an instrument which is not recognized as a lethal weapon and sentence for this crime is religious, as fasting, giving alms to the poor, and blood money [45]. Moreover, alqatl alckhta' (homicide by mistake) is a fatal act which unintentionally results to death by misadventure, as when a person shoots at a goal and inadvertently kills a passerby. This killings results from unconscious acts, such as an individual who rolls over in his sleep, and this kind of crimes punished by paying a compensation and fasting two months. Likewise, alqatl bilsabab (murder by intermediate cause) is death resulting from an independent cause, as wall collapses had been recognized and in such case the offender (builder) is strictly liable and is required to pay a fine [46]. Battery or the infliction of bodily injury, is subject to retaliation or compensation if it results in serious, everlasting injury or physical disfigurement, and scholras agree on a damage's schedule of which specifies the value of human life and of various bodily parts and at the end it depends on the victim' consent and his/her family will [47].

Ta'azir Deeds: It means correction and represents crimes for which the Qur'an and Sunnah does not propose a punishment and the judge authority to penalize these offenses emerges from the sovereign's duty to defend the public welfare [48]. There are four cases in which this penalty is usually imposed: (a) acts which do not meet the technical requirements of Quesas and hudud (as attempted robbery, or assault); (b) acts, typically punished by Hudud, but due to mitigating circumstances (doubt, theft among relatives, lack of evidence at the trial) and the judge is not authorized to exercise such discretion and must convict or acquit the offender; (c) acts condemned in the Qur'an and Sunnah or contrary to the public prosperity (usury, false testimony, bribery, astrology, or palmistry, etc...), and (d) various deeds violate social norms and morals, as being not nice to somebody [49]. These criminal acts are punished in accordance with the qadi's view of the offense's gravity, the offender's background, subjective and objective culpabilities, and the public good [50]. The accessible punishments in that regard comprise traditional (corporal) punishments, as the death penalty, and flagellation, which is rarely imposed, deprivation of liberty through imprisonment or the less preventive conducts of local banishment, displacement, or expulsion. [51]. These sentences is usually guided by ijma'a alummah (community consensus), 'urf (custom) or by Qiyyas (analogy).

\section{Procedural Islamic Criminal Law: Any Due Process Guarantees?}

Procedural guarantees are set neither in the Qur'an nor the Sunnah, but are left to the ruler's discretion who is in charge of the public welfare's preservation, even this formulation, it is still is guided by various Islamic norms [52]. Under the equality standard, dhimmi (people of the book/non-Muslims) enjoy a full protection of the criminal law, and are not subject to the hudud punishment, especially for drinking or defamation, as a universal norm that should be applied [53]. A judicial decision must be inconformity with the Sharie'a spirit, otherwise it is invalid (null) [54]. The accused is presumed innocent until proven guilty (presumption of innocence), as the burden of proof rests upon the accuser (proponent), and the oath is incumbent on the one who denies, and 
doubt is to be resolved in his favor [beyond a reasonable doubt], as the Prophet's wife reportedly admonished Muslims to "[a]void condemning the Muslim to hudud whenever you can, and when you can find a way out for the Muslim then release him for it. If the imam [leader] errs it is better that he errs in favor of innocence [pardon] than in favor of guilt [punishment].” [55] Also, as a general rule, criminal evidences must meet the conclusiveness requirement until the punishment's execution, and its presentation should not be delayed as the main basis for the criminal conviction.

In the same vein, pre-trial detention mode and release on financial bail is generally not acknowledged in Islam and scholars agreed that the defendant should not be detained prior to trial since an indictment of guilt alone is not appropriate to justify an accused's confinement detention as this interferes with an person's freedom of movement which is protected by Islamic norms [56]. On the pre-trial interrogation, this is conducted by the minister of complaints, and the Qur'an explicitly forbids the use of beatings, torture, or inhuman treatment to extract a confession as sin, as this violates the accused's dignity, outcomes in a loss of confidence that creates a risk of false admissions [57]. All Muslim jurists would exclude from evidence confessions obtained under coercion (by force or deceit) based on Islamic norms that "source determines the offshoot" and "a right cannot arise out of wrong." [58]. The Islamic criminal justice system recognizes the right of both the plaintiff and the criminal to present evidence at trial and to have the opportunity of being represented by a defense-counsel (right to legal assistance) during cross-examination, at trial, and, upon conviction, and at the execution of the sentence [59]. This guarantee based on the Islamic theory of "protected interests" which ensure a person's freedom of religion; expression, knowledge, thought, and the right to self-preservation; as this theory stipulates the importance of receiving the assistance of others in safeguarding interests [60]. The attorney along with the accused are to be informed of the crimes which are being charged (inculpatory and exculpatory evidences) and has the right to attend all proceedings relating to the charges, to be informed of what occurs at proceedings in case he/she fails to attend, and to be provided the opportunity to present rebuttal evidence to interrogators [61].

On search and seizure, Islam identifies privacy right and individual's sanctity, correspondences, and names [62]. The individual, his house, properties, and communications may only be searched by investigative officers if necessary based on the public interest to preserve social security and public order [63]. The search must be authorized by a warrant based upon a probable cause that the offender committed a crime and this cause must be based either on trustworthy witnesses testimony or upon physical evidence, as proofs discovered pursuant to a search not accredited by a warrant commonly is inadmissible at the criminal trial [63]. Furthermore, the judge's credentials and characters are very significant and strict under Islamic evidentiary rules to guarantee that the defendant receives an impartial and fair trial. The qadi may be a male or a female, must possess acknowledged wisdom, intelligence, and 'adala (religious piety), and be well-versed in the Sharie' $a$ and must be above reproach in his personal behavior and should not accept favors or gifts among others [64]. Under classical Islamic law, it have been said among scholars that you can give an unjust law to a just judge, but you cannot give a just law to an unjust judge [65].

The integrity of the Islamic criminal process is protected by the fact that the evidentiary norms are strict that guarantees that criminal convictions and penalties are enforced only in cases of certain guilt. Islamic law only permits the presentation of evidence which is considered to have an extraordinary degree of direct reliability [66]. The significant mode of evidence is shahada alshohoud (testimony of witnesses). Witnesses must be sane (when observing an alleged crime and when testifying); of legal age (reached puberty age); neither dumb, mute, nor blind; and must not have been penalized for a grave act or have engaged in sinful behavior and must be of good character and 'adl (integrity) and their virtue and sense of honor must be beyond criticism, and has a duty to testify truthfully. They may not testify in cases involving blood ties or if they have an interest [67]. Hearsay evidence is inadmissible; an individual may not testify about an incident which another person purportedly observed and documents have no autonomous evidentiary value [68]. On the other hand, al-ie trafat (confessions/admissions) represents the second key form of evidence in Islamic law. A confession must be given in an open court session as several times as the number of witnesses required to prove the culprit's guilt and must be given at a separate hearing [69]. Confession under deception, torture or abuse, results in its nullification by the qadi [70]. The confessor must be sound mind (legal capacity of understanding it and understanding its legal outcomes) and of mature age and must designate the offense in detail and must be corroborated. A confession is not permissible against a codefendant and may be withdrawn at any time prior to the punishment's execution and such withdrawal will nullify the guilt's ruling [71].

\section{Conclusion and Policy Recommendations}

To conclude, we discussed the main principles of criminal law substantially and procedurally and the rules of evidence for each crime is so strict and need a lot of work to proof its commission and to apply the punishments, so it sounds stricter in application than the positive laws without any contradiction to them, so it outlined and described the essential features of Islamic criminal law. Some scholars argued that international human rights values should be interpreted, applied, and practiced by domestic cultural and religious ideals. Islamic criminal law is genuinely rooted in the revelations' tests and as such is divinely based and driven, not to remark circuitously mingled with spirituality and ethics while instructing human dignity's philosophies and life appreciation's values. So, in the end, as the Islamic human rights law charter is earlier than the HR Declaration, so we may NOT ask ourselves if Islamic law is compatible with HR so, instead, we may ask which parts of the that law or the Shariea norms are similar to the HR Declaration and how they are applied in each country. The first duty in Islamic law is to ensure a better coexistence of public benefits, to ensure common good, and to administrate justice and better governance. The second principle is trust in individuals 
and the individual's accountability towards society in which recently the former US Secretary of State, Rex Terlison emphasized in his Farwell speech at the state department. As folk's obligations come from the divine will and it should be noted that one of the main Islamic principles based on trust is the duty to accept and respect the law of the country the law of the land (supremacy law). We all know that the First generations of HR are political and civil rights, the second are the social, economic and cultural, and most importantly is the third one that based on the idea of solidarity, an innovative approach, of the collective efforts of community, together with individual duties and rights. Many legal scholars and political scientists interpret the third generation as a shared common responsibility of the society and individuals and not of the State.

As Islamic law is unique in assuring the right of personal security, alImam alGhazali, one of the most well-known Islamic academics, established what are known today as the "Five Essentials," which have become the main criteria for scholars to determine whether an idea or solution endorses the public interest. Therefore, Islam guarantees the "makasid alSharie' a alslamia/alDaruriat alKhams" (the five essential things) to all folks and forbids unjustified violation of them by the state. These essentials are (1) protecting religion, (2) protecting lives, (3) protecting lineage, (4) protecting posterity and intellect, and (5) protecting property. Additionally, Islamic law presents the structural framework for a community by preserving the legal relations among individuals and protecting the interests of one person from being attacked by another. It likewise protects individual peace and security when an individual is accused of a crime by defining the relationship between the individual and the state. In this regard as discussed, the most important principles laid down in Sharie'a are: (i) the principle of individuality of punishment, its legality, and the non-retroactivity of criminal laws.

It should bear in mind that there is an individual and a collective conception of rights and duties, since the foundation of Islam. There is in no conflict in what religious orders - the duties - with the duties that HR movements underline. The problem I see is that many folks-especially in the West-like always to look at the strict observance of Islamic law which is perplexing with terrorism issue. Sharie'a cannot be evaluated theoretically, only its application and implementation can be assessed, as every legal system has an influence from religion including the Western positive secular laws. Prosecuting terrorism and preventing radicalization are difficult tasks that will require an immense commitment of resources and focus by many governments. However, Arabs, Europeans, Americans, as well as people from around the world have already suffered greatly at the hands of terrorist organizations. Terrorism will continue to disrupt and destroy the lives of civilians unless governments increase efforts to fight the ideology of these organizations and its folks' mentality along with changing the underlying conditions that are conducive to radicalization.

\section{References}

1. Joseph Dainow (1966) The Civil Law and the Common Law: Some Points of Comparison, 15 AM, J Comp 3: 419-35.

2. Irshad Abdal-Haqq (2002) Islamic Law: An Overview of its Origin and Elements, 7 J Islamic L. \& Culture 27, 57 (noting the different sources of Islamic law and the meaning of the public interest's interpretation).

3. M. Cherif Bassiouni \& Gamal Badr, the Sharia'h: Sources, Interpretation, and Rule-Making, 1 UCLA J Islamic \& Near E. L. (2002), at 135, 150. Qur'an is the word of God to the Prophet Mohammad and recorded by scribes and edited by scholars. Sunnah (prophet's traditions) is the recorded statements, judgments, and even the tacit acts of Mohammad which explain, detail, and supplement Qur'an. Ijm'a is a consensus regarding the interpretation or application of Sharie'a question of law or fact and where Muslim jurists or community's members of reach a consensus concerning a legal matter, their interpretation becomes reference and deference for future generations. A rule by consensus entails a participation of an adequate number of jurists, who reach a unanimous decision, based on an unequivocal statement of agreement by each scholar.

4. Id., at 140-141. Qiyyas is the extension of a Sharie'a ruling in one case to a new, similar case due to the resemblance of both cases' 'ilah (effective cause). See also M.Cherif Bassiouni, Introduction to Islam 28 (1985).

5. N. Coulson, (1978) a History of Islamic Law (Edinburgh Univ Press).

6. John Esposito, D. Mogahed (2008) Who Speaks for Islam? What a Billion Muslims Really Think, New York: Gallup Press.

7. A. E. Mayer (1995) Islam and Human Rights: Tradition and Politics. Boulder: Westview Press.

8. B. Tamanaha (2004) on the Rule of Law: History, Politics, Theory, (Cambridge Univ Press).

9. Bassiouni, supra note 4 .

10. In 2002, Iran enacted a suspension on the application of the punishment of stoning, and in 2003, a similar decision was made concerning amputations. According to Amnesty International, however, under President Ahmedinedjad, cases of amputation have been recorded as well as one case of actual stoning, while some people in Iran are till 'waiting to be stoned to death on charges of adultery.

11. Esposito \& Mogahed, supra note 6.

12. Mayer, supra note 7.

13. Coulson, supra note 5 .

14. Id. These essentials are (1) protecting religion, (2) protecting lives, (3) protecting lineage, (4) protecting posterity and intellect, and (5) protecting property. The modern jurists added the conservation of public interests and freedoms.

15. M. Cherif Bassiouni (1982) The Islamic Criminal Justice System.

16. Matthew Lippman, Sean Mcconville, Mordechai Yerushalmi (1988) Islamic Criminal Law and Procedure: An Introduction.

17. Id. The Qur'an stipulates that principle in the following verse: "And that man hath only that for which he maketh effort," The Sunnah confirms this rule. The

Prophet said to Abi-Ramhah and his son, "He does not commit a crime against him." Qur'an 53:39 \& Sahih Al-Bukhrai. 
18. Bassiouni, supra note 4 , at 58 .

19. Id., at 64-65.

20. The only exception to this principle in Islamic jurisprudence is that a criminal law has retroactive effect if it favors the accused. For instance if the new legislation affords for a lesser sanction than the current law at the time the crime was committed then in that situation the less severe penalty is applicable. This is very similar to the principle of lenity in Western legal doctrines. The Prophet did not apply the Islamic values to persons who, prior to their acceptance of Islam, breached the Quranic injunctions like being married to two sisters at the same time, or usury.

21. Taha J. Al-Awani (1995) The Rights of the Accused in Islam, 10 ARAB L. Q. 1, at 38 in Criminal Justice In Islam: Judicial Procedure In The Shari'A (Muhammad Abdel Haleem, Kate Daniels, \& Abdel Omar Sherif, eds.,) (I.B. Tauris \& Co. Ltd., 2003), at 49.

22. Bassiouni, supra note 4 .

23. Id. This principle may seem virtuously procedural, but it also includes a substantive attitude as it prohibits lawmaking that would being not be equal in purpose, scope, and application.

24. Mohamed 'Arafa (2012) Corruption and Bribery in Islamic Law: Are Islamic Ideals Being Met in Practice?, 18 Ann. Surv. Int’l. \& Comp. L. 171, 183, at 181-182.

25. Id. Islam discussed this norm some fourteen centuries ago. Its existence under Islamic law is shown by numerous verses from the Qur'an: "We never punished until we have sent a messenger." Qur'an, 17:15. The law may penalize only those performances committed after their ban by law; the judge may enforce upon the offender only those punishments which are endorsed by law.

26. Aly Mansour, Hudud Crimes (1982) In: The Islamic Criminal Justice System 195, (C. Bassiouni ed.) 195-201.

27. Bassiouni, Quesas Crimes (1982) In: The Islamic Criminal Justice System 203, (C. Bassiouni ed.) 203-05.

28. Ghaouti Benmelha (1982) Táazir Crimes. In: Bassiouni ed., 211-55, also Muhammad Iqbal Siddiqi (1979) The Penal Law of Islam pg: 140.

29. Siddiqi, supra note 28 , at $127-28$.

30. Mansour, supra note 26.

31. The Qur'an advises "[As for] the thief, the male and the female, amputate their hands in recompense for what they committed as a deterrent [punishment] from Allah. And Allah is Exalted in Might and Wise." Qur'an, 5:38

32. Siddiqi, supra note 33, at 128. Muslims are obliged to give zakat (alms) as a commercial duty to the poor determined by the Qu'ran, and the state is required to afford the poor, so a thief who robs to survive is not subject to Hudud.

33. Mansour, supra note 26, at 199. Adultery and fornication acts destabilize marriage and may lead to family struggle, jealousy, divorce, illegitimate child births, and sometimes sexual disease's spread.

34. God says: "[A]nd those who cast it up on women in wedlock, and then bring not four witnesses, scourge them with eighty stripes, and do not accept any testimony of theirs ever-they are ungodly." A husband's defamation under lían (wife's oath) results in divorce and is not subject to penalty. See Siddiqi, supra note 33, at 53-59.

35. The Qur'an states: “[T]his is the recompense of those who fight against God and His Messenger, and hasten about the earth, to do corruption there: they shall be killed, or crucified, or their hands and feet shall alternately be struck off, or they shall be banished from the land.” Qur'an, 5:33.

36. Siddiqi, supra note 28, at 141. It should be noted that domestic exile (local banishment) or expulsion (of noncitizens) from the state can be added to the harba's sentence based on the qadi's discretion.

37. Most scholars argue that all alcoholic beverages are prohibited. The Prophet said: "He who drinks wine, whip him." Mansour, supra note 33 , at 200.

38. God says: "O believers, wine and arrow-shuffling, idols and divining arrows are an abomination, some of Satan's work; ... so avoid it; ... Satan only desires to precipitate enmity and hatred and to bar you from the remembrance of God, and from prayer." Qur'an, 4:46.

39. Qur'an, 109:6. Some extreme scholars consider apostates as considered legally dead, and if they escape to a non-Muslim territory, their belongings are is distributed among their Muslim heirs. See, e.g., Qur'an, 2:217. Siddiqi, supra note 28, at 95-106.

40. Id., at 140. If the revolutionaries' claims have robust virtue and the leader has diverged from Islamic norms, he is removed from office and subjected to ta'azir sanction and in such a case, the protesters are absolved from guilt.

41. He is legally justified in ordering the military to attack rebels who reject to lay down their lethal weapons.

42. Mansour, supra note 26, at 197, 198.

43. Bassiouni, supra note 27 , at 203. It includes voluntary and involuntarily manslaughter, intentional and non-intentional physical injury or maiming.

44. 'Arafa, supra note 24, at 189-190.

45. Id. See, e.g., Qur'an, 25:68-69, 4:93, \& 2:178.

46. Id. In wounds circumstances, the offender's sentence is the imposition of the identical harm as was inflicted on the victim.

47. Qur'an, 5:45.

48. Benmelha, supra note 28, at 222. These deeds endanger one of the foremost objectives of Islamic law (the practice of religion, the development of the lineage, the right to procreation, the right to personal security, and the right to possess property).

49. Id., at $223,224$.

50. 'Arafa, supra note 24, at 194. ("Fines as compensation and reparation for injury under Ta'azir be pecuniary. Further, there is an area of social control, where the judge's intervention is essential and his discretionary power is manifest. This is obvious in certain penalties which fall outside the scope of purely penal law and relate more to the moral, ethical, and educational theories of penology. There are several punishments designed to instill morality, such as exhortation by the judge to do good and avoid evil deeds, blame ("reproach"), and dismissal from employment for abuse of confidence.").

51. God says "Charitable donations are only for the poor and the needy, and those who work in the administration of such donations, and those whose hearts are to be won over, for the freeing of people in bondage and debtors, and to further God's cause, and for the traveler in need. This is a duty ordained by God, and God is Allknowing, Wise." See Qur'an 9:60. 
52. Id. Siddiqi, supra note 28 , at $164,165$.

53. Osman A. Al-Saleh (1982) The Right of the Individual to Personal Security in Islam, In: The Islamic Criminal Justice System, C. Bassiouni edn. pg: $55,80$. 54. God says "Judgment belongs only to God; He has commanded that you shall not serve any but Him." Qur'an 7:3.

55. The Prophet said in this respect: "Had men been believed only according to their allegations, some persons would have claimed the blood and properties belonging to others, but the accuser is bound to present positive proof" and "In case of doubt, there is no application of a haad."

56. Mohammad S. El'Awa (1982) The Basis of Islamic Penal Legislation In: The Islamic Criminal Justice System. C. Bassiouni Edn pg: 127, 140. Mohamed S. El'Awa (1983) Punishment In Islamic Law: A Comparative Study.

57. Id., at 106. The Prophet warned that "God shall torture on the Day of Recompense those who inflict torture on people in life." See, e.g., Qur'an, 67:15.

58. Id., at 107. See also Ma’moun Salama, General Principles of Criminal Evidence in Islamic Jurisprudence, in THE ISLAMIC CRIMINAL JUSTICE SYSTEM, 109, 117 (Bassiouni ed. 1982).

59. Al-Saleh, supra note 53, at 83 . In case of inability to produce the required witnesses or if they disagree to testify to the crime's details, Qarina (presumption) counts as a mode of evidence and judge can rely on it among Muslim scholars only when it is strong, meet the conditions of conclusiveness (not probative) and certainty (irrebuttable). Also, the judge customarily requests that the offender take a holy oath denying the plaintiff's claims.

60. Caliph Umar ibn 'Abd al'Aziz advised judges: "If an adversary whose eye has been blinded by another comes to you, do not rule until the other person attends. For perhaps the latter had been blinded in both eyes."

61. Awad, supra note 59 , at $95-97$.

62. God says "[D]o not enter houses other than your houses until you first ask leave and salute the people thereof..." Qur'an, 24:27-28.

63. Al-Saleh, supra note 53 , at 68-70.

64. Some scholars argued that the judge should be from a prosperous family so that he will be in a position to reject bribes, kickbacks, and inducements and will be sufficiently secure to make ostracized rulings. See Ghulam M. Azad, Conduct and Qualities of a Qadi (1985) 24 ISLAMIC STUDIES 51, 56-57.

65. Id., at 59 (discussing the qadi's features among the second Prophet's Caliph [companion]). He/she has a duty to render a fair and impartial verdict consistent with Islamic doctrines. Though there is no appeal from the qadi's judgment, a defendant may challenge (plea) to the leader ensuing the penalty's execution. If it is found the defendant was illegally penalized, the qadi will be removed from office and receive the same punishment inflicted unjustly on the defendant and the accused will be compensated. If the appellant is launched a false appeal (deceitful), he is subject to táazir sanction and a judge's descendant has the privilege to release folks if concludes have been inadequately convicted and confined by his predecessor. Al-Saleh, supra note 53, at 84 \& Siddiqi, supra note 21, at 183.

66. Awad, supra note 59. A criminal motion is opened by the plaintiff introducing his/her accusations against the defendant and if the latter denies guilt, the plaintiff/state presents the examination witnesses.

67. A witness' testimony must begin with ashhadu ("I testify") indicating that he is testifying as to matters he has personally seen and that he is certain of the truthfulness of his testimony. No other words, as "I know" or "I'm certain" is approved. All witnesses must concur in the time's description, place, and circumstances of an offense to support a conviction. The rules require that a criminal's guilt be established directly than by circumstantial evidence.

68. 'Arafa, supra note 24, at 223-224.

69. Id. In fact the qadi may attempt to circumvent these strict rules (exercise discretion within the punishment phase).

70. Id., at 225-226. See also Lawrence Rosen (1980-1981) Equity and Discretion in a Modern Islamic Legal System, 15 L. \& SOC’Y $217,227$.

71. Salama, supra note 58 , at $119,120$. 